\title{
THE EMPLOYMENT OF METAPHORS IN NAJIB'S SPEECHES ON ECONOMY
}

\author{
Nurul Hijah bte Jasman* and Zalina Mohd Kasim \\ *Universiti Teknologi Mara Malaysia and Universiti Putra Malaysia
}

\begin{abstract}
The cognitive and affective appeal of metaphor exploits subconscious discernment that is aroused non-verbally and then developed through language. It is the subliminal potential of metaphor that reinforces the performance of leadership and this explains the frequent usage of such rhetorical tool in speeches by many politicians (Charteris-Black 2011: 2). This study examines metaphors in the speeches of the sixth Prime Minister of Malaysia on the Economic Transformation Programme (ETP). The cognitive metaphor framework by Lakoff and Johnson (1980) has been utilised in examining any emerging patterns from the PM's speeches. The Metaphor Identification Procedure (MIP) as proposed by Pragglejazz Group (2007) has been adopted in the analysis of the data. The results from the analysis have shown several interesting conceptual metaphors underlying some of the metaphorical expressions in the speeches by the Prime Minister, including the ECONOMY IS A SPORT conceptual metaphor. Such findings have provided some insights into the way conceptual metaphors are used in political speeches as a way to evoke certain understanding of concepts related to the economy and also as a mechanism of persuasion.
\end{abstract}

KEY WORDS: CONCEPTUAL METAPHORS, POLITICAL DISCOURSE, ECONOMY

\section{INTRODUCTION}

In September 2010, the Economic Transformation Programme was formulated and launched by the Prime Minister of Malaysia, Dato' Sri Najib Razak, as part of Malaysia's National Transformation Programme. The main aim of this programme is to promote the country to a developed nation status by 2020 , through attracting 444 billion USD (United States Dollars) in investments, which will create 3.3 million new jobs (PEMANDU, 2013). The ETP is directed by two essential pillars, which comprise 12 National Key Economic Areas (NKEAs). Each NKEA encompasses Entry Point Projects (EPPs) and Business Opportunities (BOs). These elements serve as helping hands in ensuring the ability for the sectors to expand further up. The programme also named six Strategic Reform Initiatives (SRIs) which will provide support and apposite urge for Malaysia to compete globally. This is an important catalyst in the roadmap of the creation of a business-friendly environment in Malaysia, which is anticipated to attract valuable foreign investment. It is with the execution of NKEAs and SRIs that ETP aids in achieving Vision 2020.

As the ETP is a marathon and not a sprint, tremendous momentum to forge ahead must be forced. For the first year after it was introduced, the programme kick-started with RM179.2 billion investment, which led to 313,741 job opportunities (PEMANDU, 2013). The value dipped a little in 2012, with only RM32.1 billion investments being recorded. In 2013, the ETP proclaimed that $86 \%$, or RM 25.42 billion in investments for projects in 2011 and 2012 have been realised. The success of ETP largely depends on the participation by the private sector, but without staunch support from the 


\section{THE EMPLOYMENT OF METAPHORS IN NAJIB'S SPEECHES ON ECONOMY}

'rakyat' (the Malaysian word for 'people'), the achievement of the mission will not be without obstacles. The information regarding ETP has been disseminated to the public via various means, including the internet and mass media. What is more pertinent is how the Prime Minister conveyed the idea to the people. Given the multicultural nature of Malaysian society, there is clearly the challenge of ensuring that the message on the ETP is not only accessible to all Malaysians, but also motivates support from them. Therefore, this study investigates the conceptualisation of the notions related to the ETP in the speeches of the PM.

The assessment of the metaphors will provide a valuable and unique insight into the way a political leader utilises the linguistic and cognitive mechanism in reaching out to the public, especially one that is culturally and linguistically diverse. The findings will contribute to the existing literature and further knowledge on the understanding of human cognition and the specific cultural models involving a nation with diverse linguistic and cultural backgrounds.

The dominant focus in this study is on the use of metaphors as a tool of persuasion in the political speeches. According to Kovecses (2002), appreciation towards the use of metaphors could give a different meaning on the way one perceives things. Various studies (Charteris Black, 2009, 2011; Fairclough, 2006) have looked at metaphors as a rhetorical mechanism used by Western politicians in their speeches. The cognitive metaphor framework by Lakoff and Johnson (1980) will be utilised in examining any emerging patterns from the PM's speeches. The analysis can provide sufficient amount of information on the use of metaphors in the conceptualization of the ETP in particular and economy in general.

\section{REVIEW OF STUDIES}

Studies on metaphors in political discourse have been conducted over the years to examine how politicians use metaphors as tools of persuasion in their speeches or public statements (Meadows 2007; Charteris-Black, 2005; Ferrari, 2007; Lu \& Ahrens, 2008).

Charteris-Black (2005) has examined the employment of metaphors by influential world leaders, including Winston Churchill, Martin Luther King, Bill Clinton, Tony Blair, and Barrack Obama. The employment of metaphor by all these world leaders in their speeches is seen as bringing positive impacts to their political career paths. The study provides a lucid insight on how metaphors are a powerful tool in shaping political arguments, heightening emotive responses and creating potent political myths that later serve as a bridge between the politicians and the voters.

In a critical study of American statements on Iraq during the years 2004 and 2005, Meadows (2007) has examined the way in which Bush administration tries to create both distance and solidarity towards general social categories between the Iraqi and the Americans via metaphorical and metonymical references. The findings from this study show how metaphors and metonymies are used to instill the sense of animosity among the readers towards Saddam Hussein, and how they entail a transfer for the Iraqi people from the metaphorical victim to hero.

Lu \& Ahrens (2008) conducted a research on Taiwanese presidential speeches, focusing on the BUILDING metaphors. Based on the study, it was found that COMMUNISTS ARE DESTROYER conceptual metaphors have been utilized in the history of the country as a rhetorical strategy employed by Kuomintang presidents to instill Chinese ideology. Nonetheless, the Democratic Progressive Party president has tried to replace such a conceptual metaphor with a more positive alternative such as the 


\section{THE EMPLOYMENT OF METAPHORS IN NAJIB'S SPEECHES ON ECONOMY}

BUILDING metaphors. A study by Nuri (2008) on Israeli political discourse has shown that metaphors can be used in political discourse to change the political reality.

In a study on the speeches of Barrack Obama, Lesz (2011) has concluded that JOURNEY metaphor is the conceptual metaphor that is used the most by Obama in his political speeches. An example of JOURNEY metaphor by Barrack Obama includes AMERICA IS A LEADER IN A JOURNEY which conceptualizes the notion of the American government as progressing in a journey and thus, associates Obama's leadership with all the activities and actions that he has proven capable of doing.

Regarding metaphors in economic discourse, over the years a number of studies have looked at the ways in which metaphors structure the less tangible domain of economy. As pointed out by Hewings (cited in Herrera \& White 2000), economics is one of the most difficult subjects due to its frequent use of non-literalness of economics language. Bratoz (2004) has examined the use of metaphors in English and Slovene popular economic discourse and found that there are similarities between the two languages in the way conceptual and linguistic metaphors are used to describe concepts related to the economy. Tengku Farah et al. (2012) have looked at the metaphorical linguistic manifestations of the conceptual metaphor MARKET MOVEMENTS ARE PHYSICAL MOVEMENTS in Business Times. Kumaran (2013) has looked at the role of metaphor in a sample of Malaysian Prime Minister's texts on ETP. Two dominant conceptual metaphors that have been identified by Kumaran (2013) include ETP IS A JOURNEY and ETP IS A VEHICLE. This paper seeks to extend the analysis of Kumaran (2013) by examining twenty five ETP-related political speeches by the Prime Minister, to find other metaphorical conceptualisations on ETP that have been featured frequently in the political discourse.

\section{METHODOLOGY}

\section{Data}

Twenty five of Prime Minister's political speeches on ETP, consisting of 46,874 words ranging from 2011 to 2013 were selected to examine the frequency of metaphors related to the ETP. The speeches were obtained from the library of Perdana Leadership Foundation, a foundation that was established to preserve, develop and spread information regarding the Prime Ministers of Malaysia (Perdana, 2011).

\section{Method}

All the selected speeches were analysed through close reading in identifying the metaphorical expressions involved. The first step of identification of metaphorical expressions involved referring to the Oxford Advanced Learner's Dictionary in checking and identifying the literal and figurative meanings of the expressions.

The second step of analysis involved the Metaphor Identification Procedure (MIP) proposed by Pragglejazz group. This procedure is developed by Gerard Steen and five research assistants of Amsterdam University (Nacey, 2009). MIP offers a clear decision to metaphorical expressions identified on whether or not they convey a metaphorical meaning (Pragglejaz Group, 2007). There are four steps needed to be done in accordance to MIP. The procedures are as cited below: 
1. The entire discourse needs to be read thoroughly. This is to set up a general understanding of the overall meaning

2. Lexical units in the text discourse are to be determined

3. (a) For each lexical unit in the text, its meaning should be established context. That is, how it applies to an entity, relation, or attribute in the situation evoked by the text (contextual meaning). What comes before and after the lexical unit is taken into account.

(b) For each lexical unit, it should be determined if it has a more basic contemporary meaning in other contexts than the one in the given context. For our purposes, basic meanings tend to be

- More concrete (what they evoke is easier to imagine, see, hear, feel, smell, and taste)

- Related to bodily action

- More precise (as opposed to vague)

- Historically older.

Basic meanings are not necessarily the most frequent meanings of the lexical unit.

(c) If the lexical unit has a more basic current/contemporary meaning in other contexts than the given context, it should be decided whether the contextual meaning contrasts with the basic meaning but can be understood in comparison with it.

4. If the answer to 3-c is yes, the lexical unit needs to be marked as metaphorical (Pragglejaz Group, 2007)

Via this method, the importance of context of the selected discourse is distinguished. Below is an example on how to identify metaphor using MIP by applying it to a sentence in one of Dato' Seri Najib's speeches.

At step 2, lexical unit is determined. Slashes are used to detach one lexical unit from another.

But / if / we / deepen / our / commitment / to / economic / and / political / reform / I / believe / it / is / within / reach /

At step 3, the meaning has to be established in context, starting from the first word in the chosen discourse. After that, decision has to be made on whether or not the word is sufficiently distinct from the contextual meaning and finally step 4 is to be employed, which is whether the lexical item is used metaphorically in the context of the speech.

\begin{tabular}{|c|c|c|}
\hline \multirow[t]{4}{*}{ But } & $\begin{array}{l}\text { Contextual } \\
\text { meaning }\end{array}$ & $\begin{array}{l}\text { In this context, the conjunction 'but' indicates temporal duration. That is, } \\
\text { it introduces a noun 'if', which indicates an option to be given following } \\
\text { the lexical unit }\end{array}$ \\
\hline & Basic meaning & $\begin{array}{l}\text { The conjunction 'but' can be used to introduce a word or phrase that } \\
\text { contrasts with what was said before (e.g; His mother won't be there, but } \\
\text { his father might) }\end{array}$ \\
\hline & $\begin{array}{l}\text { Contextual versus } \\
\text { basic meaning }\end{array}$ & The contextual meaning is not in contrast with the basic meaning. \\
\hline & $\begin{array}{l}\text { Metaphorically } \\
\text { used }\end{array}$ & No \\
\hline \multirow[t]{4}{*}{ If } & $\begin{array}{l}\text { Contextual } \\
\text { meaning }\end{array}$ & $\begin{array}{l}\text { In this context, the noun 'if' is used to introduce another possible option } \\
\text { to the situation as stated in the speech. }\end{array}$ \\
\hline & Basic meaning & $\begin{array}{l}\text { The noun 'if' indicates a situation that is not certain (e.g; If he wins the } \\
\text { competition, he could be a millionaire) }\end{array}$ \\
\hline & $\begin{array}{l}\text { Contextual versus } \\
\text { basic meaning }\end{array}$ & $\begin{array}{l}\text { There is no contrast between the contextual meaning and the basic } \\
\text { meaning. }\end{array}$ \\
\hline & Metaphorically & No \\
\hline
\end{tabular}




\begin{tabular}{|c|c|c|}
\hline \multirow{5}{*}{ We } & used & \\
\hline & $\begin{array}{l}\text { Contextual } \\
\text { meaning }\end{array}$ & $\begin{array}{l}\text { In this context, the pronoun 'we' indicates a referent to all the } \\
\text { distinguished guests in the launch of Exchange Traded Bonds and Sukuk } \\
\text { (ETBS) on Bursa Malaysia }\end{array}$ \\
\hline & Basic meaning & The pronoun 'we' refers to "I and another person" or other people \\
\hline & $\begin{array}{l}\text { Contextual versus } \\
\text { basic meaning }\end{array}$ & $\begin{array}{l}\text { There is no contrast between the contextual meaning and the basic } \\
\text { meaning. }\end{array}$ \\
\hline & $\begin{array}{l}\text { Metaphorically } \\
\text { used }\end{array}$ & No \\
\hline \multirow[t]{4}{*}{ Deepen } & $\begin{array}{l}\text { Contextual } \\
\text { meaning }\end{array}$ & $\begin{array}{l}\text { In this context, the verb 'deepen' indicates an attempt in achieving a goal } \\
\text { in improving the views of others on subject matter, namely economy. }\end{array}$ \\
\hline & Basic meaning & $\begin{array}{l}\text { The verb 'deepen' indicates an action of making something, namely } \\
\text { emotion or feeling, to become deeper. (e.g; His frown deepened) }\end{array}$ \\
\hline & $\begin{array}{l}\text { Contextual versus } \\
\text { basic meaning }\end{array}$ & $\begin{array}{l}\text { The contextual meaning contrasts with the basic meaning. The abstract } \\
\text { effort in contextual meaning can be understood in terms of physical } \\
\text { effort. }\end{array}$ \\
\hline & $\begin{array}{l}\text { Metaphorically } \\
\text { used }\end{array}$ & Yes \\
\hline \multirow[t]{4}{*}{ Our } & $\begin{array}{l}\text { Contextual } \\
\text { meaning }\end{array}$ & $\begin{array}{l}\text { In this context, the determiner 'our' indicates a referent to the act of } \\
\text { making something deeper by the distinguished guests at the launching } \\
\text { ceremony. }\end{array}$ \\
\hline & Basic meaning & $\begin{array}{l}\text { 'Our' is a determiner and a possessive form of we, which shows a } \\
\text { belonging to us }\end{array}$ \\
\hline & $\begin{array}{l}\text { Contextual versus } \\
\text { basic meaning }\end{array}$ & $\begin{array}{l}\text { There is no contrast between the contextual meaning and the basic } \\
\text { meaning. }\end{array}$ \\
\hline & $\begin{array}{l}\text { Metaphorically } \\
\text { used }\end{array}$ & 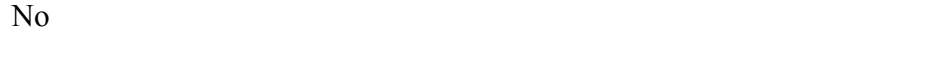 \\
\hline \multirow[t]{4}{*}{ Commitment } & $\begin{array}{l}\text { Contextual } \\
\text { meaning }\end{array}$ & $\begin{array}{l}\text { In this context, the noun 'commitment' is an effort that should be put } \\
\text { forward by the distinguished guests. }\end{array}$ \\
\hline & Basic meaning & $\begin{array}{l}\text { Commitment is a promise to behave in a particular way and the } \\
\text { willingness to work hard and give your energy and time to a job or an } \\
\text { activity. (e.g; A career as an actor requires } 100 \text { percent commitment) }\end{array}$ \\
\hline & $\begin{array}{l}\text { Contextual versus } \\
\text { basic meaning }\end{array}$ & $\begin{array}{l}\text { The contextual meaning contrasts with the basic meaning. We can } \\
\text { understand the way in which economists and politicians should give out } \\
\text { greater dedication in assurance of something good to be achieved. } \\
\text { Commitment is seen in terms of a physical object that is concrete and } \\
\text { touchable. }\end{array}$ \\
\hline & $\begin{array}{l}\text { Metaphorically } \\
\text { used }\end{array}$ & Yes \\
\hline \multirow[t]{4}{*}{ To } & $\begin{array}{l}\text { Contextual } \\
\text { meaning }\end{array}$ & $\begin{array}{l}\text { In this context, preposition 'to' signals an indication of introduction of } \\
\text { something (an adjective phrase in this discourse) }\end{array}$ \\
\hline & Basic meaning & As a preposition, 'to' shows the beginning of something. \\
\hline & $\begin{array}{l}\text { Contextual versus } \\
\text { basic meaning }\end{array}$ & $\begin{array}{l}\text { There is no contrast between the contextual meaning and the basic } \\
\text { meaning. }\end{array}$ \\
\hline & $\begin{array}{l}\text { Metaphorically } \\
\text { used }\end{array}$ & No \\
\hline \multirow[t]{2}{*}{ Economic } & $\begin{array}{l}\text { Contextual } \\
\text { meaning }\end{array}$ & $\begin{array}{l}\text { In this context, the adjective 'economic' refers to the state of the } \\
\text { country's economic growth. }\end{array}$ \\
\hline & Basic meaning & Economic indicates a connection with the trade, industry and \\
\hline
\end{tabular}


Contextual versus basic meaning Metaphorically

used

And

Political

I

Believe

It

Contextual

meaning

Basic meaning

Contextual versus

basic meaning

Metaphorically

used

Contextual

meaning

Basic meaning

Contextual versus

basic meaning

Metaphorically

used

Reform

meaning

Basic meaning

Contextual versus basic meaning

Metaphorically

used

Contextual

meaning

Basic meaning

Contextual versus development of wealth of a country.

There is no contrast between the contextual meaning and the basic meaning.

No

In this context, the conjunction 'and' is used to link to matters as talked by the Prime Minister in the speech.

Conjunction 'and' indicates a connection between words.

There is no contrast between the contextual meaning and the basic meaning.

No

In this context, the adjective 'political' indicates the Country's power and status.

Political is connected with the state, government or public affairs.

The contextual meaning is the same as the basic meaning.

No

In this context, the noun 'reform' indicates a change for improvement that the government is trying to impart to the existing system of the country likely to say the economic and political system.

'Reform' can be used to introduce improvement of a system, an organization and a law.

The contextual meaning is the same as the basic meaning.

No

In this context, the pronoun 'I' indicates a referent to the speaker, Dato' Sri Najib Tun Razak.

'I' is a pronoun used by the speaker to refer to himself or herself.

The contextual meaning is the same as the basic meaning.

No

In this context, the verb 'believe' indicates an assured feeling of the speaker that a sustained economic growth of the country is achievable.

'Believe' carries a meaning of to think that something is true or possible although one is not completely certain. (e.g; Police believe that the man may be armed)

The contextual meaning is in contrast with the basic meaning but it can be understood by comparison with it. We can understand abstract effort in terms of physical effort.

Yes

In this context, the pronoun 'it' refers to the condition of maintaining positive economic growth.

'It' is used as a pronoun to refer in a general way to a situation that is just described.

The contextual meaning is the same as the basic meaning 


\section{THE EMPLOYMENT OF METAPHORS IN NAJIB'S SPEECHES ON ECONOMY}

\begin{tabular}{|c|c|c|}
\hline & basic meaning & \\
\hline & $\begin{array}{l}\text { Metaphorically } \\
\text { used }\end{array}$ & No \\
\hline Is & $\begin{array}{l}\text { Contextual } \\
\text { meaning }\end{array}$ & In this context, 'is' is a referent to the condition described before. \\
\hline & Basic meaning & $\begin{array}{l}\text { 'Is' is a copular linking verb 'to be'. It does not have a different basic } \\
\text { meaning. }\end{array}$ \\
\hline & $\begin{array}{l}\text { Contextual versus } \\
\text { basic meaning }\end{array}$ & The contextual meaning is the same as the basic meaning \\
\hline & $\begin{array}{l}\text { Metaphorically } \\
\text { used }\end{array}$ & No \\
\hline Within & $\begin{array}{l}\text { Contextual } \\
\text { meaning }\end{array}$ & $\begin{array}{l}\text { In this context, 'within' indicates a distance but not a physical space } \\
\text { from a positive economic growth to success }\end{array}$ \\
\hline & Basic meaning & $\begin{array}{l}\text { 'within' refers to something which is inside or surrounded in a place or } \\
\text { area. }\end{array}$ \\
\hline & $\begin{array}{l}\text { Contextual versus } \\
\text { basic meaning }\end{array}$ & The contextual meaning is the same as the basic meaning \\
\hline & $\begin{array}{l}\text { Metaphorically } \\
\text { used }\end{array}$ & No \\
\hline Reach & $\begin{array}{l}\text { Contextual } \\
\text { meaning }\end{array}$ & $\begin{array}{l}\text { In this context, the verb 'reach' describes the reformation of economic } \\
\text { and political as something that can be touched or achieved }\end{array}$ \\
\hline & Basic meaning & 'reach' is to arrive to the place that you are travelling to. \\
\hline & $\begin{array}{l}\text { Contextual versus } \\
\text { basic meaning }\end{array}$ & $\begin{array}{l}\text { The contextual meaning is in contrast with the basic meaning. We can } \\
\text { understand the way in which Dato' Seri Najib describes economic and } \\
\text { political reforms as something which can be touched and got through } \\
\text { commitment and hard work. }\end{array}$ \\
\hline & $\begin{array}{l}\text { Metaphorically } \\
\text { used }\end{array}$ & Yes \\
\hline
\end{tabular}

Based on the identified metaphorical expressions, the underlying conceptual metaphors are identified. As explained by Lakoff \& Johnsson (1980), conceptual metaphors generally consist of a target domain and a source domain, and in a conceptual metaphor, mappings from the latter would help to construct a richer understanding of the former. For example, the metaphorical linguistic expressions such as "our innovation steered us through the economic crisis", "setting on a right path", and "Bioeconomy roadmap for Malaysia" map the source domain of JOURNEY onto the target domain of ECONOMIC TRANSFORMATION. These metaphors share a common purpose in the conceptualization of the ETP. That is, to evoke the notion of a movement along a passage with a particular destiny at the end.

\section{ANALYSIS AND DISCUSSION}

Generally, the total number of words of the selected speeches was 46,874, with 914 words for the shortest speech and 3477 words for the longest speech. Based on the analysis, there are a number of conceptual metaphors that tend to occur frequently in the speeches of the Prime Minister. These metaphors include ECONOMY IS A SPORT/GAME and ECONOMY IS A CHEMICAL SUBSTANCE. This paper will illustrate some linguistic examples for these conceptual metaphors and discuss how the source domain helps to highlight particular aspects of the economy. 


\section{THE EMPLOYMENT OF METAPHORS IN NAJIB'S SPEECHES ON ECONOMY}

\section{Economy Is a Sport/game}

This is one of the most frequently used conceptual metaphors in the speeches of the Prime Minister. Below are some of the examples of the linguistic manifestations of this metaphor that can be found from the data:

i. $\quad$ Malaysia must be a key player in a multi-trillion dollar regional market.

ii. We have demonstrated nimbleness in reacting to shocks to the system before - in particular, our resilience and our innovation steered us through the economic crisis that swept through Asia at the end of the 20th century.

iii. There is a dark cloud descending over us as Europe struggles to find its feet in tackling the debt crisis.

$i v$. All these, signal a need for us to "up-our-game", so to speak, and truly embrace the vast opportunities that these new technologies bring.

v. Naturally, different players within the public and private sectors will have different objectives but we all have only one goal.

The conceptualisation of the economy in terms of a sport or a game in many ways helps to highlight several aspects of the domain of the economy. A sport or game is an activity involving physical exertion and skill, and is often of a competitive nature. By describing the economy in terms of a sport, the Prime Minister (PM) appears to be focusing on the element of competitiveness, whereby those who are involved in it, i.e. businessmen, entrepreneurs, etc. will have a role to play, either as individuals or as a team (just like in a sport) to overcome their competitors and thus, become successful in this domain, or in other words, win the game. This can be seen in example $(i)$, where Malaysia is described as one entity ( $a$ key player) who needs to have a fundamental role in the multitrillion dollar regional market. The description of a key player places the country at the forefront of the economic market, and emphasises the importance of leading/controlling the economy in the region, just like a main player would do in a game. In example $(v)$ the word player is used again, but in this context it refers the more specific entities within the countries, i.e. the businessmen, companies (different players within the public and private sectors). By mentioning other players in the game the economy- the PM indirectly acknowledges their importance in the domain of economy and as indicated at the end of the sentence, "we all have only one goal", the PM is stressing the need for everyone to focus in the game and be united for one objective of the game, which is to strengthen the country's economy.

If looked closely, example (ii), which describes the resilience of the country's economy in facing the economic crisis, contains a number of conceptual metaphors such as the JOURNEY metaphor (steered), and ECONOMY IS A FORCE metaphor (economic crisis that swept through Asia). But at the beginning of the sentence, the word nimbleness, which is related to the notion of quick and light movement, can be associated with the SPORTS metaphor. By using a word that is associated with agility when playing sports, the PM seems to be describing in a positive way the quick reaction by the government towards the economic crisis that occurred at the end of the $20^{\text {th }}$ century and its skillfulness in overcoming the financial trouble that plagued many Asian countries at the time. In example (iii), the word tackling also helps to conceptualise the idea of reacting to debt crisis by describing the situation in terms of confronting the opposition in a game. 


\section{THE EMPLOYMENT OF METAPHORS IN NAJIB'S SPEECHES ON ECONOMY}

\section{Economy Is a Chemical Substance}

Based on the data, it can be seen that the employment of source domain CHEMICAL SUBSTANCE in the PM's speeches on economy conveys a negative connotation. Below are some of the examples found in the data:

vi. If Islam were corrosive to growth, Malaysia's economy would not have expanded on average

vii. In 2010, youth unemployment was $25 \%$, in North Africa $24 \%$ and this is due to sluggish economic development in the Middle East. The expanded of economy at such levels is toxic.

viii. But while economics may be a medicine and toxic at times, some predictions are worth making, especially if they are supported by the facts.

The PM has linked the chemical substance to the bad condition of the economy. Negative elements of chemical substance, such as toxic and tonic, appear to have been used in the mappings. These elements are well known for their hazardous characteristics. For example, certain toxic substances cause pollution as well as physical impairment to those who are exposed to them and this chemical substance can also lead to death when it is introduced to the body via respiratory organs. When the substance is absorbed through the pores, this can cause commotion to the lung and liver in particular.

As illustrated in example (vi), by describing the effects of Islam on the economy as corrosive, the PM has highlighted the idea of how the religion will negatively affect the growth of the country's economy (note that another metaphor i.e. ECONOMY IS A PLANT is being used here). The notion of erosive, destructive or deleterious evoked from the use of the word corrosive emphasises the adverse effect of Islam on the country. However, one must also take note here that example (vi) is in fact a conditional statement and was uttered with the intention to convince the audience that Islam, which is also the official religion of Malaysia, has not been detrimental to the growth of the country's economy, because otherwise, the country's economy would not have expanded on average.

In example (vii), once again, the chemical substance (toxic) has been used to describe the negative situation of the economy. To some extent, the use of the word toxic in this sentence also insinuates danger since it is often associated with death or serious illness or side effects. By using the concept of toxicity, the PM in some ways is persuading the audience that sluggish economic development is not something to be taken lightly and has to be avoided and prevented. In example (viii) however, the economics has been described as both a medicine and a toxin. This time, the metaphorical expressions help to highlight both the positive and negative aspects of the business world.

\section{CONCLUSION}

There are several prominent reasons for the employment of metaphors in political discourse, namely as a tool to persuade, impart the notion of sounding right, criticize, and instigate. The metaphors employed in a given discourse revitalize, reinstate and re-motivate the listeners to understand the discourse thoroughly and assist the listeners to comprehend the underlying meanings intended to be conveyed by the speakers. In this paper, two conceptual metaphors that have been utilised to describe the economy in the Prime Minister's speeches have been analysed to see how they help to highlight certain aspects of the economy and evoke certain understanding of the notion of the economy in the context of a discourse that is related to the ETP. The findings have shown how the choice of source domains can be a highly effective way of highlighting certain aspects of the economy that the PM wishes to focus on in his speeches. It is interesting to see how the different metaphors enabled the $\mathrm{PM}$ to focus on both positive and negative aspects of economy and at the same time serve as a rhetorical tool to evoke a more optimistic perception of the Economic Transformation Programme. 


\section{THE EMPLOYMENT OF METAPHORS IN NAJIB'S SPEECHES ON ECONOMY}

\section{REFERENCES}

Cameron, Lynne \& Low, Graham (1999). Researching and applying metaphor. New York: Cambridge University Press.

Charteris-Black, Jonathan (2005). Politicians and rhetoric: The persuasive power of metaphor. New York: Palgrave Macmillan.

Charteris-Black J (2006). Britain as a container: immigration metaphors in the 2005 election campaign. Discourse and Society 17(5): 563-581

Cheng, X. (2009). Chinese Metaphors in Political Discourse: How the Government of the People's Republic of China Criticizes the Independence of Taiwan. Retrieved from http://cardinalscholar.bsu.edu/handle/123456789/193398 on December 2, 2012.

Chow, M. Y. V. (2011). A Comparative Study of the Metaphor Used in The Economic News Articles in Britain and Hong Kong. Retrieved from etheses.bham.ac.uk/1705/ on December 14, 2012.

Deignan, Alice (2005). Metaphor and corpus linguistics. Cambridge: Cambridge University Press.

Ferrari, F. (2007). Metaphor at work in the analysis of political discourse: investigating a 'preventive war' persuasion strategy. Retrieved from comphacker.org/comp/eng1335fosen/files/2012/08/Ferrari2007.pdf on December 23, 2012.

Group, P. (2007). MIP: A Method for Identifying Metaphorically Used Words in Discourse. Retrieved from eprints.lancs.ac.uk/27203/ on January 12, 2013.

Lakoff, George (1986). The meanings of literal. Metaphor and Symbolic Activity, 1, 291-296.

Lakoff, George (1987). Women, fire, and dangerous things: What categories reveal about the mind. Chicago: University of Chicago Press.

Lakoff, George (1993). The contemporary theory of metaphor. In A. Ortony (Ed.), Metaphor and thought (pp. 202-251, 2nd ed.). Cambridge: Cambridge University Press

Lakoff, George \& Johnson, Mark (1980). Metaphors we live by. Chicago: Chicago University Press.

Lesz, B. (2011). To Shape the World for the Better: An Analysis of the Metaphors In The Speeches of Barrack Obama. Retrieved from munin.uit.no/bitstream/handle/10037/3540/thesis.pdf on January 14, 2013.

Lu, L \& Ahrens, K. (2008). Ideological influence on Building metaphors in Taiwanese presidential speeches.

Retrieved from http://www.kathleenahrens.com/images/Ideological_Influences_and_BUILDING_metaphor s_in_Taiwanese_Presidential_Speeches.pdf on November 28, 2012. 


\section{THE EMPLOYMENT OF METAPHORS IN NAJIB'S SPEECHES ON ECONOMY}

Meadows, B. (2007). Distancing and Showing Solidarity via Metaphor and Metonymy in Political Discourse: A Critical study of American statements on Iraq during the years 2004-2005. Journal of CADAAD, Vol 2 (October 1), 2007.

Nuri, D. (2008). The metaphorical annihilation of the Second Lebanon War (2006) from the Israeli political discourse. Retrieved from das.sagepub.com/content/19/1/5.full.pdf on December 12, 2012.

Rundell, M. (2002). Oxford Advanced Learners Dictionary. England: Pearson Education Limited

Roche, C. (2012). The Economy, The Human Body and The System Flows. Retrieved from http://pragcap.com/the-economy-the-human-body-system-flows on December 24, 2012.

Stalhammar, M. (2006). Metaphors in Commercial Contracts. Retrieved from www2.english.su.se/nlj/metfest_08/Twardzisz_08.pdf on January 14, 2013.

Semino, Elena and Masci, Michela (1996). Politics is football: Metaphor in the discourse of Silvio Berlusconi in Italy. Discourse and society, 7, 243-269.

Taiwo, R. (2008). Metaphors in Nigerian Political Discourse. Retrieved from http://www2.english.su.se/nlj/metfest_08/Taiwo_08.pdf on December 14, 2012.

Tengku Farah, T. M., Afida, M. A., Rafik-Galea, S. and Zalina, M. K. 2012. Getting physical with the market: A study of metaphors in the Business Times. Pertanika Journal of Social Sciences \& Humanities, 20(3): 881-896.

Zinken, J. (2003). Discourse Metaphors. Retrieved from www.port.ac.uk/departments/academic/.../filetodownload,68139,en.pdf on January 3, 2013. 